\title{
Joaquín Álvarez Barrientos, Los hombres de letras en la España del siglo XVIII. Apóstoles y arribistas. Madrid, Castalia, 2006.
}

Aunque sin desdeñar frecuentes incursiones en otros campos, durante los últimos años el hilo argumental de este libro ha presidido la vida investigadora de Joaquín Álvarez Barrientos. Los hombres de letras en la España del siglo XVIII. Apóstoles y arribistas es la consecuencia, pues, de una labor paciente y apasionada, tal como reclamaba el ambicioso planteamiento elegido. Una elección que estaba más que justificada, dado que un territorio, tan necesario de explorar, para las letras españolas del XVIII, aguardaba todavía que alguien lo abordase. En Francia, en Inglaterra, en Alemania, ya se contaba con buenos trabajos de esta índole, en cambio el mundo hispánico carecía de un estudio sistemático con tales características.

Una vez más, muestra Álvarez Barrientos que la capacidad de un buen investigador no se reduce sólo al rigor con el que emprende su tarea; antes hay que saber intuir qué cuestiones indispensables quedan por colmar. $\mathrm{Y}$, a este respecto, la República española de las Letras dieciochescas era un envite latente, pero que exigía, por una parte, adentrarse en algunos campos aún por desbrozar, y, sobre todo, organizar, cohesionar e interpretar los muchos trabajos parciales que andaban sueltos. Sucedía en este caso como en otras parcelas dieciochistas: en los últimos años, la investigación ha aportado bastante material nuevo, pero no se ha procedido con igual diligencia a relacionarlo y sistematizarlo. Por otro lado, un empeño de este tipo sólo podía ser llevado a cabo por alguien que, a un conocimiento amplio del siglo XVIII español, uniera buenas antenas familiarizadas con lo acaecido en las letras europeas, en ese mismo ámbito. Y para esa incursión, Álvarez Barrientos también contaba con un buen bagaje de información y lecturas.

Pero aún había otras dificultades: un proyecto de esta magnitud debía enfocarse desde una perspectiva literaria - puesto que son escritores y literatos su objetivo primordial-, mas era indispensable conocer los procesos sociológicos, estéticos, políticos e históricos en los cuales estaba inmerso el país y, al mismo tiempo, los cambios de gusto, de sentimientos y de opciones morales que entraron en juego en un siglo tan inestable. Una buena serie de acontecimientos alteraron tanto las costumbres públicas como los hábitos privados, y, sin tenerlos en cuenta — surgimiento de las Academias, de los salones, de las tertulias, de la prensa periódica - no era posible comprender los avatares de los hombres de letras.

Deslindar cómo se acuña el concepto de República Literaria — y cómo se convierte en moneda frecuente en el discurso de los literatos- es el primer 
cometido del libro. Y, tal como será norma a lo largo del mismo, una mirada a lo sucedido en Europa ayuda a situar la singularidad española. Desde esta perspectiva, necesariamente unida a la de la imprenta, el siglo XVIII será recorrido como un complejo camino hacia la profesionalización y la independencia de unos escritores que, en las centurias anteriores, no llegaron nunca a constituir un gremio que autorizara y defendiera su actividad. Pero, finalmente, la demanda de un nuevo público lector y la apertura de otros espacios para el ocio y la diversión — gabinetes, bibliotecas públicas y privadas, cafés, teatros— les obligó a replantear el sentido del trabajo literario y a reflexionar sobre su sitio en la sociedad. Se creó una situación que Joaquín Álvarez Barrientos sintetiza así:

Estos poetas que no dependen de un monasterio ni de la administración, se preguntan si hay que escribir por dinero, se enfrentan a la contradicción existente entre el hecho de buscar la sabiduría y producir obras hermosas, y a la ausencia de recompensa, que desemboca en una vida miserable, cuando no marginal.

La respuesta a este tipo de dilemas será muy dispar a tenor de la diversidad de actitudes personales e ideológicas de los escritores dieciochescos. Mas el interés de la investigación se centraba precisamente en mostrar cuánta confrontación generó el elegir y defender cada una de las opciones posibles. A las posturas éticas y vitales se unían necesidades inmediatas e intereses creados. Para mostrar el amplio espectro de decisiones adoptadas, el autor ofrece una buena gama de voces disonantes. Por una parte, los grandes nombres son convocados para expresarse, pero también una larga serie de autores menos conocidos dan cuenta de su opinión. Esta aportación documental — que ha debido exigir un considerable esfuerzo de indagación - le presta su gran valor al libro, con su acopio de voces extraídas literalmente de un gran número de fuentes, pero calculadas en su extensión precisa: lo suficiente para facilitar al lector material de primera mano, sin convertir por ello el libro en un centón acumulativo de citas, debilidad frecuente en otros investigadores.

Gran interés ha puesto Álvarez Barrientos en sobrepasar y abrir las más socorridas imágenes —ya tan homologadas— del escritor dieciochesco. Por su estatuto e incidencia social, resultaba fácil reconocer a sabios, eruditos, periodistas y literatos y por sus opciones ideológicas se han distinguido muy bien a los ilustrados de los tradicionalistas. Mas a partir de ahí, se había indagado poco en la caracterización de otros modelos. Sin embargo, tipos muy persistentes encerraban peculiaridades casi exclusivas del siglo, que pedían ser diferenciados y catalogados. El filósofo, el papelista, el semidocto, la literata, el charlatán, el violeto y el bel esprit reciben, por fin, ese esperado tratamiento analítico y, sobre 
todo, con los dos últimos se realiza una admirable disección, que facilitará en lo sucesivo un más atinado uso de su función por parte de los estudiosos.

Tras esta parte sobre el escritor y la sociedad, lo que atañe a lo público pierde relevancia y la mirada del investigador se vuelca hacia la imagen que el hombre de letras da de sí mismo y cómo la exterioriza. Se presta atención al papel desempeñado por las competencias y odios personales: un capítulo que confirma que también en el XVIII el fenómeno de la rivalidad fue un incitante de la producción literaria. Más sorprendente es el capítulo dedicado a la representación de la salud como rasgo diferenciador del escritor. Una visión positivista que aclara cuán lejos estaba todavía la delectación romántica en la enfermedad y en la muerte, pero que de algún modo ya la presiente. Observar cómo se construyen las biografías, qué rasgos merecen destacarse en unas memorias, supone revelar el tipo de reconocimiento al que el literato aspira, en unos años en los que el retrato pictórico de escritores también se difunde. Se detiene Álvarez Barrientos en señalar la actitud melancólica y de ensoñación que transmiten cuadros tan ejemplares como el de Jovellanos de Goya o la estampa de este último El sueño de la razón produce monstruos.

Los aspectos cuantitativos de la industria impresora que por entonces se inicia también han merecido ser acogidos en estas páginas porque «en el siglo fueron 7593 los españoles que publicaron algún texto», lo cual supone una República Literaria, para un país como España, bastante poblada. Los beneficios que daba la venta de libros, los empleos literarios más socorridos, las recompensas, el papel de los censores, manifiestan una cara generalmente oculta de la profesión literaria. Igualmente debates como el del plagio y la originalidad y, el consecuente, de los derechos de autor, no por tener una apariencia menos noble, podían ser eludidos en un libro que quiere mostrar que la República de las Letras necesitaba, para subsistir, poner en funcionamiento toda su fisiología de entrañas, cavernas y cocinas. Para superar este encuentro con lo real cotidiano, la última parte de la obra eleva de nuevo sus objetivos y tras exponer las esperanzas, logros y fracasos de los proyectos institucionales, utiliza el epílogo para presentar al nuevo hombre de letras que será consecuencia de todos los procesos expuestos. Gracias al transcurso de la República Literaria «se afianzó al escritor como ciudadano con derechos y deberes», dispuesto para servir y servirse de una «cultura que se abría a todos, se nacionalizaba, se convertía en patrimonio». De esa cultura es heredero este libro de Joaquín Álvarez Barrientos. La memoria literaria de aquel siglo XVIII ya puede ser, gracias a estas páginas, memoria de todos. 